\title{
The effects of the flipped classroom on deep learning strategies and engagement at the undergraduate level
}

\author{
Kevser HAVA* \\ Yozgat Bozok University Bozok Education Faculty Yozgat, Turkey \\ ORCID: 0000-0003-3822-6796
}

\begin{tabular}{|c|c|}
\hline Article history & The flipped classroom is a popular teaching method where course \\
\hline $\begin{array}{l}\text { Received: } \\
04.07 .2020\end{array}$ & $\begin{array}{l}\text { content is transferred to students through online resources to } \\
\text { implement more active learning strategies in-class time. The study }\end{array}$ \\
\hline $\begin{array}{l}\text { Received in revised form: } \\
01.10 .2020\end{array}$ & $\begin{array}{l}\text { aims to investigate the effects of the flipped classroom on deep } \\
\text { learning strategies and engagement at the undergraduate level, } \\
\text { alongside students' perspectives toward the flipped classroom. The }\end{array}$ \\
\hline $\begin{array}{l}\text { Accepted: } \\
17.10 .2020\end{array}$ & $\begin{array}{l}\text { research involved } 97 \text { freshmen students in Turkey. During a 7-week } \\
\text { application process, the experimental group students learned the }\end{array}$ \\
\hline Key words: & course content with the flipped classroom method, whereas the \\
\hline $\begin{array}{l}\text { Flipped classroom, } \\
\text { deep learning strategy, } \\
\text { student engagement, } \\
\text { student perspectives. }\end{array}$ & $\begin{array}{l}\text { control group students learned the course content through the } \\
\text { traditional method. The findings of the study revealed that the } \\
\text { flipped classroom was more effective than the traditional method } \\
\text { in terms of using deep learning strategies and increasing the levels } \\
\text { of cognitive and emotional engagement. However, there was no } \\
\text { difference in behavioral engagement levels between the } \\
\text { experimental and control groups. The findings also showed that } \\
\text { viewing pre-recorded videos before coming to class enabled } \\
\text { students to comprehend course content better and easier. Flipped } \\
\text { learning enabled students to develop their research and application } \\
\text { skills. Technical facilities were the biggest difficulty for students in } \\
\text { flipped learning. The implications for flipped learning are also } \\
\text { discussed, including several techniques for controlling students' } \\
\text { viewing lecture videos and providing alternative course materials } \\
\text { to students. }\end{array}$ \\
\hline
\end{tabular}

\section{Introduction}

In recent years, there has been a radical change in educational environments towards student-centered and self-regulated learning. Recent developments in higher education also point to more effective and student-centered learning environments. Although the constructivist philosophy is widely accepted in education and is present in the vision of many educational institutions, educators cannot devote enough time to active learning activities due to the large lectures and fixed schedules. Therefore, educators have been trying to find new strategies and approaches to enhance the effectiveness of the teaching and learning process and to transform students into active learners (FindlayThompson \& Mombourquette, 2014).

\footnotetext{
*Correspondency: kevserhava@gmail.com
} 
Technological advances in the twenty-first century allow students to access online resources that are useful for both teaching and learning. Also, it has become easier for teachers to present multimedia resources to students through online services such as YouTube and TeacherTube (Olakanmi, 2017). For this reason, digital tools and resources have become an essential part of the teaching and learning process, especially at the undergraduate level. Educators are encouraged to adopt blended learning environments that combine technology with traditional teaching. In this context, the flipped classroom, which is one of the student-centered and flexible learning environments, has become popular in higher education due to the emergence of user-friendly and cost-efficient technologies (Chen, Yang, \& Hsiao, 2016; Steen-Utheim \& Foldnes, 2018).

\section{Theoretical Framework}

\section{What is the Flipped Classroom?}

The flipped classroom is a type of blended learning, where course content is transferred to students through online resources (e.g. videos, e-books, PowerPoint presentations) outside the classroom (Burke \& Fedorek, 2017). This allows students the opportunity to participate in various active learning activities such as question-answer, discussion, group work, and problem-solving during course time (Findlay-Thompson \& Mombourquette, 2014; Şengel, 2016). The course hours are mostly devoted to interactive activities to enable students to have a clear understanding and reinforcement of the concepts they view in pre-recorded videos (La Marca \& Longo, 2017). Students can also learn the course content at their own pace by pausing, rewinding, and fast-forwarding these videos without any time and space limitations (Chuang, Weng, \& Chen, 2018; Moos \& Bonde, 2016; Sun, Wu, \& Lee, 2017). Besides, students can focus on their learning needs without getting bored by the content they have already learned. Through in-class activities, teachers can get a chance to identify students' misunderstandings about the course content (Davies, Dean, \& Ball, 2013). Teachers have more different roles in the flipped classroom such as being theme experts, instructional designers, and media developers than they have in traditional teaching methods (Shih \& Tsai, 2017). Despite this, in traditional teaching, students are introduced course content in-class hours and expected to follow the curriculum planned by instructors (Sun et al., 2017).

There are some misconceptions about the implementation of the flipped-classroom approach. These are mainly teachers' needing to create their videos, minimization of teachers' responsibilities, and reduction in student-teacher interaction (Filiz \& Kurt, 2015; Şengel, 2016). There are also some concerns that students, who are unprepared for the course, might not participate in learning activities and fail during class time (Blau \& Shamirinbal, 2017). Besides, students may not have access to technical facilities at home (Altemueller \& Lindquist, 2017). However, the flipped classroom improves students' self-discipline and self-regulation skills (Adnan, 2017) because it requires students to view videos in advance and to manage their learning processes (Lai \& Hwang, 2016).

\section{Surface and Deep Approaches to Learning}

Students, who have different learning styles, personality traits, knowledge, and skill levels, receive education together in the same learning environment. For this reason, many educators might have difficulty in achieving an academic standard in crowded classrooms (Biggs, 1999). In this respect, teachers should consider student differences to 
implement effective and productive learning since many cognitive factors such as epistemological beliefs and approaches to learning affect teaching and learning processes (Phan, 2006). The approach to learning, which varies in every student, is a combination of strategy and motivation that students use to complete a specific task or solve a problem (Biggs, 1991).

It is found that students adopt different approaches to learning while performing a specific task (Marton \& Saljo, 1976). The approaches to learning are divided into two categories: deep and surface. Students, who adopt a surface learning approach, use low levels of cognitive activity because they intend to exert minimum effort to fulfill a task (Biggs, 1990). These students tend to memorize details of information and accept new situations and ideas without criticizing (Biggs \& Tang, 2011; Gijbels, Segers, \& Struyf, 2008). Contrary to that, a deep learning approach requires the use of strategies such as understating new ideas critically, linking new ideas and concepts, and associating new knowledge with previous knowledge (Biggs, 1990). Therefore, students, who adopt a deep learning approach, show higher engagement and interest in in-class activities (Senemoğlu, 2011). The surface approach is based on extrinsic motivation while the deep approach is based on intrinsic motivation to understand, and includes the strategy to seek meaning (Biggs, 1990, 1991; Hall, Ramsay, \& Raven, 2004).

It is generally accepted that a deep learning approach leads to high-quality educational outcomes (Hall et al., 2004). The choice of students' approaches to learning is highly affected by the use of innovative methods and techniques in learning environments (La Marca \& Longo, 2017). Nevertheless, undergraduate educators have difficulty in designing and developing learning environments that support deep and active learning strategies (McLean, Attardi, Faden, \& Goldszmidt, 2016). In this context, the flipped classroom could be an alternative to the traditional method in promoting students' deeper learning through active and constructive processes (Danker, 2015; Moos \& Bonde, 2016; Y1lmaz \& Baydas, 2017) since students have to prepare for the course content outside of formal class time.

\section{Student Engagement}

Student engagement is a multi-dimensional concept that is associated with the frequency of student participation in academic and non-academic activities and their desire for these activities (Willms, 2003). However, engagement is more than participation (Trowler, 2010). Fredricks, Blumenfeld \& Paris (2004) conceptualized three dimensions of engagement as behavioral, cognitive, and emotional, which are widely accepted by researchers in the literature. The behavioral dimension is based on participation; it includes attendance in academic, social, and extracurricular activities (Fredricks et al., 2004). According to Jamaludin \& Osman (2014), high behavioral engagement leads to active learning processes with the support of learning environments. Value of learning, autonomy, and personal goals are the indicators of cognitive dimension (Appleton, Christenson, \& Furlong, 2008; Steen-Utheim \& Foldnes, 2018). The emotional dimension relates to interest, enthusiasm, or negative reactions towards activities, teachers, and peers (Fredricks et al., 2004).

Student engagement is considered as a predictor of learning and academic success, meaning that disengagement entails low academic success (Fredricks et al., 2004; SteenUtheim \& Foldnes, 2018; Willms, 2003). Thence, educators should consider active 
learning processes and various factors viz. learners' prior experience, motivation, and knowledge while planning a lesson as student engagement does not occur automatically (Jovanović, Gašević, Dawson, Pardo, \& Mirriahi, 2017). The flipped classroom is believed to provide more student engagement than traditional teaching (Burke \& Fedorek, 2017; Clark, 2013; Elmaadaway, 2018) since it enables students to engage with pre-class activities that prepare them for in-class activities.

The Aim and Significance of the Study

Despite the increasing popularity of the flipped classroom, a recent meta-analysis study conducted by Zainuddin, Haruna, Li, Zhang, \& Chu (2019) indicates there is insufficient empirical evidence about the effects of flipped classroom implemented in learning environments. On the other hand, previous studies (Jovanović et al., 2017; McLean et al., 2016) claim that there is a gap in the literature about the effects of the flipped classroom on students' approaches to learning. Within this context, we tried to address the following research questions:

(1) Does the flipped classroom affect students' approaches to learning in comparison with the traditional method?

(2) Does the flipped classroom affect students' engagement levels in comparison with the traditional method?

(3) What are the students' perspectives toward the flipped classroom?

\section{Methodology}

\section{Research design}

In this study, a mixed-method design was employed by combining qualitative and quantitative research methods. Qualitative research was conducted to support the results revealed in quantitative research. For the quantitative part, a quasi-experimental pretestposttest design was used to answer the first research question, and a posttest-only control group research design was used to answer the second research question. Qualitative data were obtained through interviews.

\section{Participants}

The participants of this study are first-year undergraduates $(\mathrm{N}=97)$ who are enrolled at the departments of Elementary Education and Pre-School Education at a midsized public university in Turkey. One of these two departments was randomly determined as experimental (Pre-School Education) and the other (Elementary Education) as a control group. The university is located in a low-level province in terms of socio-economic parameters. Many students did not have personal computers and internet access. They stated that they had watched videos via their smartphones by using the internet connection in their dormitories. Some students stated that they had visited the library to watch videos at weekends. A few students said that they had downloaded videos from YouTube and shared them with other friends. In the study, to make sure the students watch videos, they were asked to take notes while watching the lecture videos. At the beginning of the lessons, the course notes of the students were checked regularly i.e. every week by the instructor. None of the students had a flipped learning experience before taking part in this study. The distribution of the students to the groups according to their gender is presented in Table 1 . 
Table 1. The distribution of the students to the groups according to their gender

\begin{tabular}{lccc}
\hline Groups & Female & Male & Total \\
\hline Control & 35 & 11 & 46 \\
Experimental & 46 & 5 & 51 \\
Total & 81 & 16 & 97 \\
\hline
\end{tabular}

\section{The Application Process}

This study was conducted in an undergraduate introductory course called "Computer I". This course was a three-credit, mandatory course about basic principles of computer concepts and Microsoft Office software such as Word, and Excel. The students attended the class once a week for two and a half hours for seven weeks in a computer lab. The computer lab had an Internet connection, a projector, and computers for each student. Before the application process, the students were asked to register in the course through Edmodo Learning Management System and they gained experience with Edmodo by uploading various tasks into this system.

Before the application process began, the implementation of flipped learning was explained to the experimental group students. For example, they were told that lecture videos should be watched before coming to the class and that assignments would only be performed during the class period. The instructor weekly shared the links of lecture videos, which were previously recorded by various content producers on YouTube, with the experimental group students. Each week, the students viewed and studied the lecture videos before the class. Watching these videos took about 3 to 20 minutes. During the class period, the instructor sometimes explained some parts of the course content at the beginning of the course for the experimental group because some students stated they did not have a clear understanding although they had watched videos rigorously. Following that, the students completed various assignments, which were created by the instructor within the course period. Two examples of Word and Excel assignments used in the application process are presented in Figure 1. In these assignments, the students were expected to follow instructions such as opening a blank page and creating shapes. While the students were completing the assignments, the instructor walked around the classroom and provided direct assistance for the students asking for help. The students also helped each other while performing some assignments. Finally, the students uploaded their completed assignments to the Edmodo. An image of the application process is presented in Figure 2.

On the other hand, for the control group, the instructor only lectured the course content during class time. Lectures in the control and experimental group had the same course content. Since the control group students learned the course content during class time, they had less time to perform their assignments. Therefore, the control group students performed fewer assignments compared to the experimental group students. They uploaded their completed assignments to the Edmodo, as well. The same instructor taught both groups. Details about the course content are presented in Table 2.

Table 2. Course Content

\begin{tabular}{clcc}
\hline Week & \multicolumn{1}{c}{ Course Content } & $\begin{array}{c}\text { Control } \\
\text { N.A* }\end{array}$ & $\begin{array}{c}\text { Experimental } \\
\text { N.A }\end{array}$ \\
\hline 1 & MS Word (Basic text formatting) & 2 & 4 \\
2 & MS Word (Inserting a table, an image, etc.) & 2 & 4 \\
3 & MS Word (Creating a table of content, and figure) & 2 & 3 \\
\hline
\end{tabular}




\begin{tabular}{clll}
\hline 4 & $\begin{array}{l}\text { MS Excel (Creating basic formulas such as addition, } \\
\text { subtraction, etc.) }\end{array}$ & 3 & 4 \\
5 & $\begin{array}{l}\text { MS Excel (Logical expressions such as IF, NESTED } \\
\text { IF, OR, AND) }\end{array}$ & 3 & 5 \\
6 & $\begin{array}{l}\text { MS Excel (COUNTIF, COUNTIFS, SUMIF) } \\
\text { MS Excel (Inserting a graphic, filter and creating a } \\
\text { pivot table, subtotal) }\end{array}$ & 3 & 5 \\
\hline
\end{tabular}

$* N . A=$ Number of Assignments
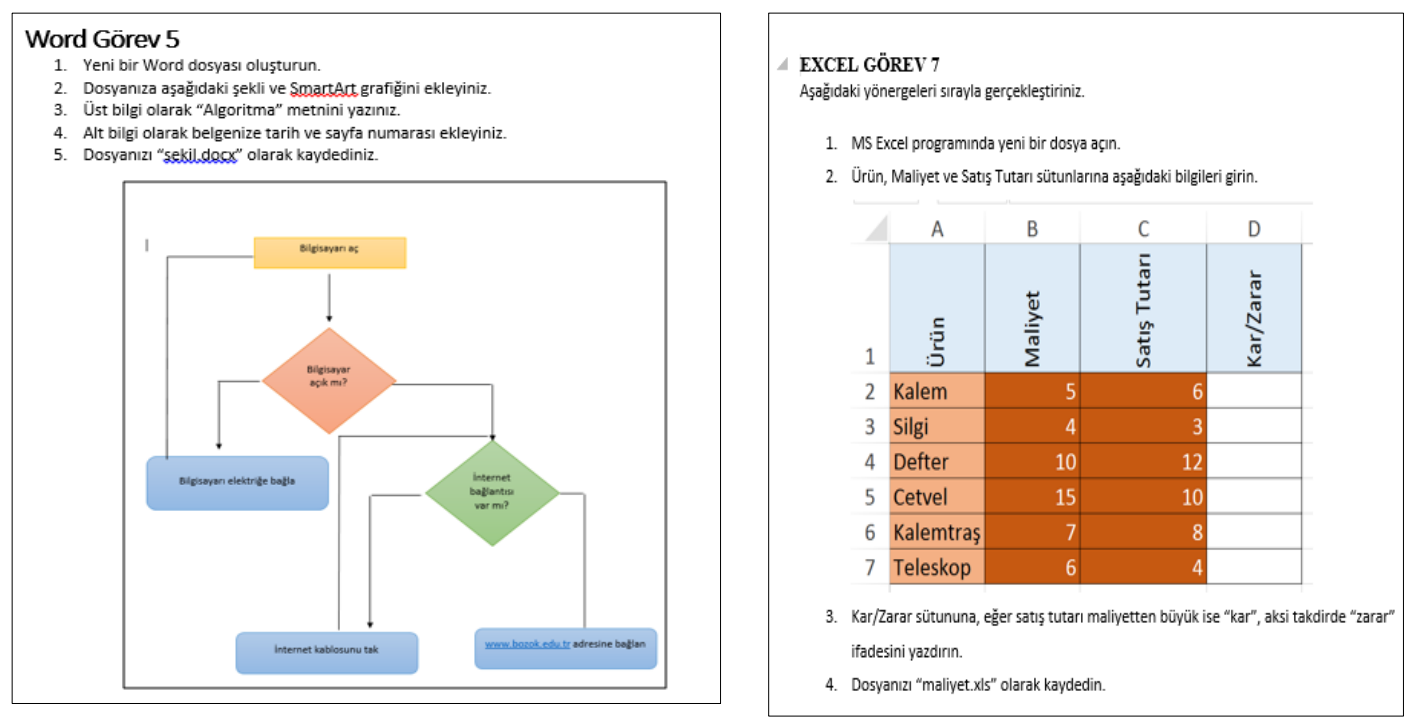

Figure 1. Examples of Word and Excel assignments used in the application process

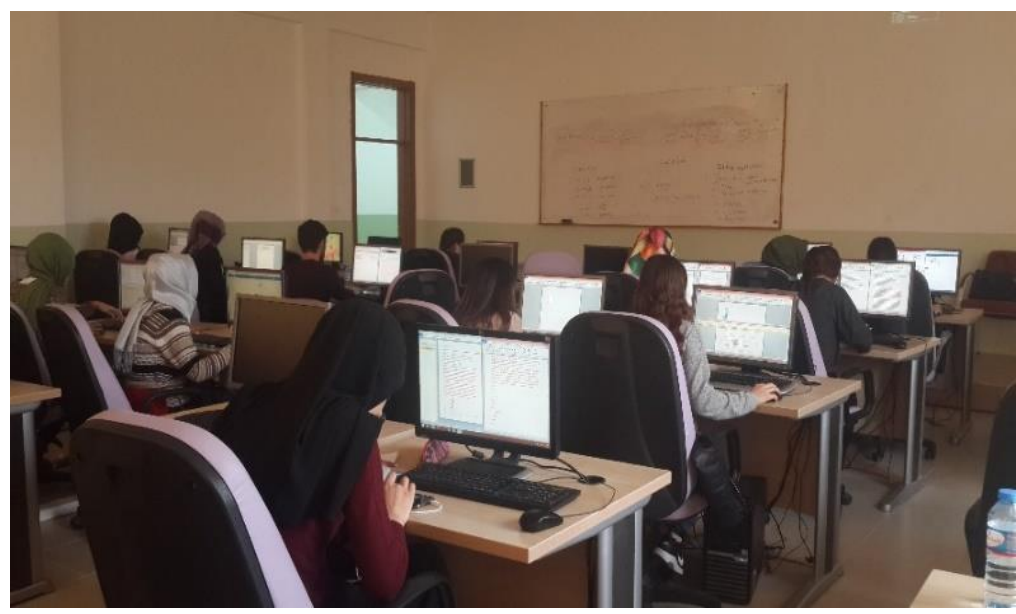

Figure 2. Experimental group students only performed assignments in-class hours

\section{Data Collection Tools}

The data were collected via a study-process questionnaire, a student engagement questionnaire, and a semi-structured interview form. The first data collection tool was a study-process questionnaire, which was used to measure approaches of students to learning in both groups. The questionnaire was administered to both groups at the beginning and the end of the application process. This questionnaire was originally developed by Biggs, Kember, and Leung (2001). It was adapted into Turkish by Önder 
and Beşoluk (2010). The instrument is a 5-point Likert-type scale with levels from "Always" to "Never". The instrument comprises of 20 items in two different factors with deep learning and surface learning. The internal reliability coefficient of the deep learning dimension is 0.78 while the internal reliability coefficient of the surface learning dimension is 0.74 . Sample items in this questionnaire include: 1) Working from time to time gives me deep personal satisfaction. 2) Even if I do not understand some course content, I go over and over again until I memorize it.

The second data collection tool, a student engagement questionnaire, was used to measure the engagement level of the students after 7 weeks. This questionnaire was administered to both groups at the end of the application process. This structured questionnaire was developed by Jamaludin and Osman (2014). The instrument is a 5-point Likert-type scale with levels from "Always" to "Never", including three dimensions as behavioral, cognitive, and emotional. The questionnaire was translated into Turkish, and this version was reviewed by a linguist. Modifications were made based on his feedback. Face validity was ensured by consulting one expert in the field. For the construct validity of the student engagement questionnaire, confirmatory factor analysis was performed. AMOS was used in the data analysis. The model indices were $\mathrm{CMIN} / \mathrm{DF}=2.10, \mathrm{RMR}=.081$, GFI $=.67$, AGFI $=.61, \mathrm{CFI}=.71$, RMSEA $=.107$. Since the sample size was too small, the results showed that some indices were below or above the threshold mark. The Cronbach Alpha reliability coefficient for the questionnaire was found to be 0.91 for this study. It was 0.82 for the first sub-factor, 0.80 for the second sub-factor, and 0.82 for the third sub-factor. Sample items in this questionnaire include: 1) I listen carefully to everything that is said in class. 2) I always ask the instructor about difficult content. 3) The teaching method practiced by the instructor is enjoyable.

A semi-structured interview form was also used to find out the students' perspectives on the flipped classroom. The interview questions were adapted from Yang (2017). At the end of the application process, twelve experimental group students who regularly viewed all lecture videos and completed all assignments were interviewed individually. Before conducting interviews, verbal consent was obtained from all students who were assured that the interviews would not be shared with anyone and would be used only for scientific purposes. The interview lasted approximately 10-15 minutes.

\section{Data Analysis}

The IBM SPSS 24.0 was employed to examine levels of the two groups, including approaches to learning and engagement levels. To examine the normality of the quantitative data, the Kolmogorov Smirnov test was employed. An independent sample t-test was performed to determine the effects of the flipped classroom concerning approaches to learning. For student engagement, one-way multivariate analysis of variance (MANOVA) was conducted between experimental and control groups regarding dependent variables called "Behavioral Engagement", "Cognitive Engagement", and "Emotional Engagement". The statistical significance level was set at 0.05.

All qualitative data were analyzed using conventional content analysis. Firstly, twelve interview data were transcribed and the students were coded as S1 to S12. Each transcript was carefully read a couple of times by the researcher to drive codes by highlighting the text. Some notes were also taken on first thoughts and impressions about student responses. Then, the codes are divided into certain categories based on how they are 
related to each other.

\section{Findings}

\section{Research Question 1. Does the flipped classroom affect students' approaches to learning in comparison with the traditional method?}

To examine the equivalence of experimental and control groups, before the application process, the scores that the students got from the pre-study process questionnaire were analyzed. The average scores of both groups obtained from the prequestionnaire on approaches to learning were compared via Independent samples t-test. The results were presented in Table 3 .

Table 3. The independent t-test result for students' approaches to learning before the application process

\begin{tabular}{llllllll}
\hline Variable & Group & N & M & SD & df & T & p \\
\hline \multirow{2}{*}{ Deep learning } & Experimental & 51 & 3.52 & .46 & 95 & -1.63 & .100 \\
& Control & 46 & 3.69 & .51 & & & \\
\multirow{2}{*}{ Surface learning } & Experimental & 51 & 2.67 & .59 & 95 & 0.78 & .938 \\
& Control & 46 & 2.68 & .68 & & & \\
\hline
\end{tabular}

As shown in Table 3, our findings demonstrated that there was not any statistically significant difference between experimental and control group students on their deep learning scores before the application process $\left[\mathrm{t}_{(95)}=1.63, \mathrm{p}=.100, \mathrm{p}>.05\right]$. It was also found that there was not any statistically significant difference between experimental and control groups on their surface learning scores before the application process $\left[\mathrm{t}_{(95)}=0.78\right.$, $\mathrm{p}=.938, \mathrm{p}>.05]$.

Table 4. The independent t-test result for students' approaches to learning after the application process

\begin{tabular}{llllllcc}
\hline Variable & Group & N & M & SD & df & t & p \\
\hline Deep learning & Experimental & 51 & 3.76 & .47 & 95 & -2.80 & .006 \\
& Control & 46 & 3.46 & .59 & & & \\
Surface learning & Experimental & 51 & 3.27 & .70 & 95 & -1.29 & .199 \\
& Control & 46 & 3.08 & .72 & & & \\
\hline
\end{tabular}

As shown in Table 4, the findings illustrated that there was a significant difference between experimental and control group students in terms of deep learning variables after the application process $\left[\mathrm{t}_{(95)}=2.80, \mathrm{p}=.006, \mathrm{p}<.05\right]$. The experimental group students had a higher mean score $(M=3.76)$ compared to the control group students $(M=3.46)$. Besides, the effect size of deep learning was calculated to be 0.56 , indicating a medium to large effect size (Cohen, 1988). This implied that the flipped classroom had medium effects on students' deep learning approach compared to the traditional method. On the other hand, in terms of surface learning variables, it was found that there was not a significant difference between the experimental and control group students $\left[\mathrm{t}_{(95)}=1.29, \mathrm{p}=.199, \mathrm{p}\right.$ $>.05]$. 


\section{Research Question 2. Does the flipped classroom affect students' engagement levels in comparison with the traditional method?}

To analyze whether there was any significant difference in engagement levels of students between the two groups, a multivariate analysis of variance (MANOVA) was conducted. The results of the one-way MANOVA test are summarized in Table 5. Significant differences were found among student engagement levels on the three subscale scores, $\mathrm{F}_{(3,93)}=3.479, p<.05$; Wilk's lambda $=0.889$. The multivariate eta squared, $\eta 2$, indicates the effect size, and a value of 0.101 means that only $10.1 \%$ of the multivariate variance of the dependable variables was associated with the instructional method.

Univariate analyses of variances (ANOVAs) on each subscale were conducted as followup tests to the one-way MANOVA. To control for Type I error across the three ANOVAs, the Bonferroni method was used. The differences between the control and experimental group on the second and third subscale were significant; experimental group students had higher cognitive and emotional engagement levels than control group students.

Table 5. The one-way MANOVA results for the subscales of the student engagement

\begin{tabular}{lccccc}
\hline \multirow{2}{*}{ Subscale } & \multicolumn{2}{c}{ Instructional Method } & & & \\
\cline { 2 - 3 } & $\begin{array}{c}\text { Control group } \\
\text { mean } \\
\text { (SD) }\end{array}$ & $\begin{array}{c}\text { Experimental } \\
\text { group mean } \\
\text { (SD) }\end{array}$ & $F$ & Sig. & $\eta 2$ \\
\hline Behavioral & $3.35(.40)$ & $3.34(.46)$ & 0.31 & .862 & .000 \\
Cognitive & $3.68(.68)$ & $3.95(.58)$ & 4.34 & .040 & .044 \\
Emotional & $3.45(.58)$ & $3.71(.60)$ & 4.56 & .035 & .046 \\
\hline
\end{tabular}

\section{Research Question 3. What are the students' perspectives toward the flipped classroom?}

The students were asked several questions to obtain data about their experiences and opinions on the flipped classroom. The main themes and categories that emerged from the data are presented in Figure 3. As seen in Figure 3, there are three themes (benefits, challenges, suggestions) and twelve categories.

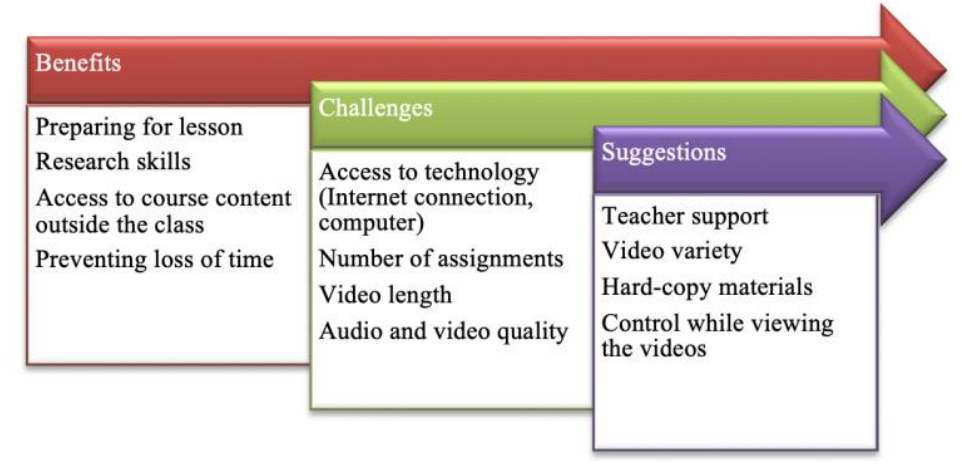

Figure 3. Themes and categories emerging from the analysis of qualitative data

\section{Benefits of flipped learning}

Many students in the current study stated that they had positive opinions about the flipped classroom approach, and this teaching method provided many advantages to them. Ten students $(88 \%)$ expressed that viewing pre-recorded videos prior to coming to the 
class allowed them to be prepared for the lesson. Hence, they had the chance to comprehend the course content easier. In this regard, a student said, "Viewing the videos before the lesson was more effective for us". Another student expressed his opinion in the following way:

It was very beneficial for watching videos before coming to the class. You could understand the course content easier. Last week, I did not understand anything in the lesson because I had not watched the videos. Therefore, I could not complete my assignments. However, I watched the videos this week and could complete my assignments. [S1]

Nine students (75\%) reported that they had developed their research skills through the flipped classroom. They stated that they researched on YouTube or other platforms about the course content when they failed to understand it in the videos. S3 said "... I watched different videos on YouTube. I also searched for different materials from different sources. It helped me improve my research skills and gain different perspectives." Some students reported that they applied commands and functions step by step in the Office program while watching the videos and that this practice enabled them to improve their application skills. For example, a student commented "While watching the videos, I opened the MS Excel software. Whatever I saw on the video, I applied them from the beginning to the end. That way, it was easier to complete my assignments in the class." Apart from that, many students expressed that the course hours were completely devoted to the assignments since they had already learned the course content through videos. Thereby, the loss of time in the class was prevented. In this regard, S8 stated "This method was useful in terms of time. For example, if the teacher had spent time lecturing, there would be less time for the activities." Six students (50\%) reported that since videos were the main course materials, accessing them at any time and any place was an advantage for them. In this respect, S12 expressed his opinion as follows:

I missed small details while the teacher was lecturing in the class. When I went home and reviewed the lecture notes, I was constantly questioning what it was. But thanks to this video method, I downloaded videos on my phone. In this way, I could watch videos and practice them again. Therefore, it was very useful to me. The subjects are stuck in my mind because I constantly repeated. [S12]

\section{Challenges of flipped learning}

It was found that the biggest difficulty for the students was technical facilities for flipped learning. Four students (33\%) stated that they did not have personal computers or internet connection in their dormitory. Due to this very reason, they went to the library to watch videos at weekends. For example, S8 stated her negative opinion on this topic: "Having to watch videos constantly was a little bit annoying. In my opinion, the flipped classroom had pros and cons. To exemplify, we went to the library to watch these videos every weekend."

Some students mentioned that the number of assignments they had to complete during class time was too many, and the duration of the course was not sufficient for completing the assignments. It is suggested that a balance should be established between the number of assignments and the duration of the course. Some students may be challenged in performing assignments although they have learned the course content outside the classroom. In this sense, the course period may not be sufficient for the performance of 
assignments. That being said, many students uttered that the length and quality of the videos were important factors affecting their concentration levels. In this respect, S8 expressed "Videos should be simple and clear. For example, we did not understand anything since some of the videos were very long. We understood the subjects better on shorter videos". Similarly, S12 stated that:

The sound quality of some videos was a bit poor. For example, in one of the Excel videos, there was excessive fan noise. Also, the resolution of some videos was too low. So, I had to watch it a few times because I did not understand it. [S2]

\section{Suggestions for flipped learning}

In the study, the students made some suggestions for a more effective implementation of flipping learning. Firstly, the students underpinned that teacher support was very important for understanding subjects better and completing assignments successfully. Parallel to these views, it was observed that some students had difficulty in performing their assignments although they had watched the videos. To illustrate, S10 proposed "We came to the classroom by watching these videos. Before starting the assignments, it could be better if you had explained the subjects that we did not understand. The teacher could do a general review before giving the assignments". Along with from that, it was also observed that some students who had not watched the videos had difficulty performing their assignments, and tried to ask for help from their classmates. In this regard, some students expressed that they could not complete their assignments since they helped their unprepared classmates. These students stated that it would have been more helpful to hold a quiz at the beginning of the course so that all would watch videos. In addition, the students expressed that course resources could be supported by different videos or hard-copy materials. On the other hand, a student claimed that lectures should have been recorded by teachers as she could have a better understanding of a familiar voice like her teacher.

\section{Discussion and Conclusion}

In the present study, we addressed the following question. To what extent does the flipped classroom affect students' approaches to learning and their engagement level? Students in the experimental group learned the course content outside the classroom (flipped learning) whereas students in the control group learned the course content in the classroom (traditional model) and performed fewer assignments than the experimental group students.

The results showed a significant difference between the groups on the use of deep learning approaches in favor of the experimental group. These findings were compatible with the studies of Danker (2015) and McLean et al. (2016). The results of this study showed that there was no difference between experimental and control groups in terms of surface learning approaches. As mentioned earlier, surface learning was not something that was desired for students to adopt. Based on the literature, we expected that the flipped classroom would increase the use of deep learning strategy more than traditional learning. It is believed that the flipped classroom will enable students to gain different perspectives through various lecture videos, improve their application and research skills via implementing several assignments, and enhance students' responsibility for their learning. The qualitative findings also support the above-mentioned claims. According to Danker (2015), students should take responsibility for their learning to obtain higher- 
order thinking skills. Students become cognitively more engaged by constructing their learning while completing assignments in the flipped classroom (Blau \& Shamir-inbal, 2017; Jamaludin \& Osman, 2014). Also, Shih and Tsai (2017) find out that students are satisfied with courses and exert more effort on learning in the flipped classroom.

Another finding of this study is that the flipped classroom enhances students' engagement in cognitive and emotional dimensions more than traditional learning. However, it is found that students' behavioral engagement levels are not different for the two groups. It seems that studying course content outside the class and participating in active learning exercises allow students to feel more engaged than traditional learning (Clark, 2013; Cronhjort, Filipsson, \& Weurlander, 2018; Elmaadaway, 2018; Steen-Utheim \& Foldnes, 2018). In these contexts, higher engagement levels of the experimental group students, observed in this study, could be attributed to the above-mentioned contributions of the flipped classroom. In recent studies (Akçayır \& Akçayır, 2018; Karabulut-ilgu, Cherrez, \& Jahren, 2018), it has also been reported that flipped learning yielded important educational outcomes, in particular, satisfaction and engagement.

Regarding students' opinions on flipped learning, similar to previous studies (Adnan, 2017; Akçayır \& Akçayır, 2018; Altemueller \& Lindquist, 2017; Şen \& Hava, 2020; Şengel, 2016; Steen-Utheim \& Foldnes, 2018; Yang, 2017), this study yielded positive outcomes concerning learning experiences. Many students were enthusiastic about studying course content before coming to the class. The previous studies in Turkey also had parallel results with this study since they reported that students had positive opinions on flipped learning which provides better preparation for the lessons and helps students become active learners in the classrooms (Şen \& Hava, 2020; Tütüncü \& Aksu, 2018). Nevertheless, as mentioned earlier, there was a concern that unprepared students might fail in-class activities (Lai \& Hwang, 2016). Within the study, many students realized that they could not complete assignments without watching the course videos in the first weeks. Nevertheless, they became more aware of their learning process. For this reason, there was a decrease in the number of students who came to the course without watching videos in the weeks that followed. In a similarly vein, Sletten (2017) claimed that developing students' self-regulated strategies needed to take some time at the start of a flipped class.

The interview results also showed that some students demanded lecture videos to be created by the instructor. Likewise, previous studies (Gouia \& Gunn, 2016; Rose, 2009) indicated that students preferred instructor made-videos since they felt more connected to the instructor. However, it could be a burden and time-consuming for teachers to create their videos by pre-recording their teaching (Akçayır \& Akçayır, 2018; Phillips, 2016; Yang, 2017). Some students stated that having access to other videos on YouTube was an advantage. The presence of many resources on the Internet could support students' learning while, at the same time, adversely affecting their levels of concentration (Lai \& Hwang, 2016). Yang (2017) found that finding or making proper videos was the main concern for teachers. For a successful implementation of the flipped classroom, it is also important to present quality online learning materials to the students in terms of video and audio quality (Akçayır \& Akçayır, 2018; La Marca \& Longo, 2017).

The findings also showed that it could be difficult to transform a traditional class into a flipped class due to a lack of facilities (Davies et al., 2013). Similarly, Post, Deal, \& Hermanns (2015) found that students experienced financial challenges such as paying 
more for high-speed internet and going to the library to watch videos. Taking this into account, it is suggested that instructors should take the availability of technical facilities and students' digital skills into consideration while deciding whether to implement the flipped classroom or not.

Another clear outcome from this study was that scaffolding learning for each student was highly important in flipped learning. In the flipped classroom, the role of the teacher is to support students in the classroom activities rather than transfer the knowledge to students (Steen-Utheim \& Foldnes, 2018). Therefore, teachers should provide meaningful learning, and help students overcome problems in flipped learning (Y1lmaz \& Baydas, 2017). Another advantage of flipped learning is to use class time more efficiently for supporting students who need extra help (Davies et al., 2013).

\section{Implications and Future Research}

Considering all these results, we could offer some suggestions for instructors who plan to use the flipped classroom. First, to ensure students watch videos, they should be tested or required to take notes while watching videos. Second, educators need to consider the length of the lecture videos. This study revealed that the students were negatively affected by long videos with low audio and video quality. Third, a balance should be established between the number of assignments and the duration of the course. Some students may be challenged in performing assignments although they have learned the course content outside the classroom. Therefore, the course period may not be sufficient for the performance of assignments. Fourth, students might be provided with alternative lecture videos, e-books, and hard-copy materials, which will enable them to gain different perspectives.

As in any educational study, this study is also bound by some limitations. The first limitation of the study is that students' engagement levels were not measured before the application process. Future studies could employ the pretest-posttest quasi-experimental design to ensure the generalizability of the findings. The second limitation is that the qualitative data were analyzed by only one researcher. So, no reliability coefficient could be calculated. Besides, since the instructor and the researcher were the same people, it was not possible to take field notes during class-time. This limitation could also have influenced the interpretation of the findings of our study. As a result, in future studies, the study could be repeated addressing the above-mentioned limitations.

\section{References}

Adnan, M. (2017). Perceptions of senior-year ELT students for flipped classroom : A materials development course. Computer Assisted Language Learning, 30(3-4), 204-222.

Akçayır, G., \& Akçayır, M. (2018). The flipped classroom : A review of its advantages and challenges. Computers \& Education, 126, 334-345.

Altemueller, L., \& Lindquist, C. (2017). Flipped classroom instruction for inclusive learning. British Journal of Special Education, 44(3), 341-358.

Appleton, J. J., Christenson, S. L., \& Furlong, M. J. (2008). Student engagement with school: critical conceptual and methodological issues of the construct.

Psychology in the Schools, 45(5), 369-386.

Biggs, J. (1990). Effects of language medium of instruction on approaches to learning. Educational Research Journal, 5, 18-28. 
Biggs, J. (1991). Approaches to learning in secondary and tertiary students in Hong Kong: Some comparative studies. Educational Research Journal, 6, 27-39.

Biggs, J. (1999). What the student does: Teaching for enhanced learning. Higher Education Research \& Development, 18(1), 57-75.

Biggs, J., Kember, D., \& Leung, D. Y. P. (2001). The revised two factor study process questionnaire : R-SPQ-2F. British Journal of Educational Psychology, 71, 133149.

Biggs, J., \& Tang, C. (2011). Teaching for quality learning at university (4 ${ }^{\text {th }}$ ed.). Open University Press.

Blau, I., \& Shamir-inbal, T. (2017). Re-designed fl ipped learning model in an academic course : The role of co-creation and co-regulation. Computers \& Education, 115, 69-81.

Burke, A. S., \& Fedorek, B. (2017). Does flipping promote engagement?: A comparison of a traditional, online, and flipped class. Active Learning in Higher Education, 18(1), 11-24.

Chen, S., Yang, S. J. H., \& Hsiao, C. (2016). Exploring student perceptions, learning outcome and gender differences in a flipped mathematics course. British Journal of Educational Technology, 47(6), 1096-1112.

Chuang, H., Weng, C., \& Chen, C. (2018). Which students benefit most from a flipped classroom approach to language learning? British Journal of Educational Technology, 49(1), 56-68.

Clark, K. R. (2013). Examining the effects of the flipped model of instruction on student engagement and performance in the secondary mathematics classroom. Journal of Educators Online, 12(1), 91-116.

Cohen, J. (1988). Statistical power analysis for the behavioral sciences ( $2^{\text {nd }}$ ed.). Hillsdale, NJ: Lawrence Erlbaum Associates.

Cronhjort, M., Filipsson, L., \& Weurlander, M. (2018). Improved engagement and learning in flipped-classroom calculus. Teaching Mathematics and Its Applications, 37(3), 113-121.

Danker, B. (2015). Using flipped classroom approach to explore deep learning in large classrooms. The IAFOR Journal of Education, 3(1), 171-186.

Davies, R. S., Dean, D. L., \& Ball, N. (2013). Flipping the classroom and instructional technology integration in a college-level information systems spreadsheet course. Educational Technology Research and Development, 61(4), 563-580.

Elmaadaway, M. A. N. (2018). The effects of a flipped classroom approach on class engagement and skill performance in a blackboard course. British Journal of Educational Technology, 49(3), 479-491.

Filiz, O., \& Kurt, A. A. (2015). Flipped learning: Misunderstandings and the truth. Journal of Educational Sciences Research, 5(1), 215-229.

Findlay-Thompson, S., \& Mombourquette, P. (2014). Evaluation of a flipped classroom in an undergraduate business course. Business Education\&Accrediation, 6(1), 63-72.

Fredricks, J. A., Blumenfeld, P. C., \& Paris, A. H. (2004). School engagement: Potential of the concept, state of the evidence. Review of Educational Research, 74(1), 59-109.

Gijbels, D., Segers, M., \& Struyf, E. (2008). Constructivist learning environments and the (im) possibility to change students' perceptions of assessment demands and approaches to learning. Instructional Science, 36(5-6), 431-443. 
Gouia, R., \& Gunn, C. (2016). Making mathematics meaningful for freshmen students: Investigating students' preferences of pre-class videos. Research and Practice in Technology Enhanced Learning, 11(2), 1-8.

Hall, M., Ramsay, A., \& Raven, J. (2004). Changing the learning environment to promote deep learning approaches in first-year accounting students. Accounting Education, 13(4), 489-505.

Jamaludin, R., \& Osman, S. Z. M. O. (2014). The use of a flipped classroom to enhance engagement and promote active learning. Journal of Education and Practice, 5(2), 124-131.

Jovanović, J., Gašević, D., Dawson, S., Pardo, A., \& Mirriahi, N. (2017). Learning analytics to unveil learning strategies in a flipped classroom. Internet and Higher Education, 33, 74-85.

Karabulut-ilgu, A., Cherrez, N. J., \& Jahren, C. T. (2018). A systematic review of research on the flipped learning method in engineering education. British Journal of Educational Technology, 49(3), 398-411.

La Marca, A., \& Longo, L. (2017). Addressing student motivation, self-regulation, and engagement in flipped classroom to decrease boredom. International Journal of Information and Education Technology, 7(3), 230-235.

Lai, C.-L., \& Hwang, G.-J. (2016). A self-regulated flipped classroom approach to improving students' learning performance in a mathematics course. Computers \& Education, 100, 126-140.

Marton, F., \& Saljo, R. (1976). On qualitative differences in learning, outcome and process. British Journal of Educational Psychology, 46, 4-11.

McLean, S., Attardi, S. M., Faden, L., \& Goldszmidt, M. (2016). Flipped classrooms and student learning: not just surface gains. Advances in Physiology Education, 40(1), 47-55.

Moos, D. C., \& Bonde, C. (2016). Flipping the classroom: Embedding self-regulated learning prompts in videos. Technology, Knowledge and Learning, 21(2), 225242.

Olakanmi, E. E. (2017). The effects of a flipped classroom model of instruction on students' performance and attitudes towards chemistry. Journal of Science Education and Technology, 26(1), 127-137.

Önder, İ., \& Beşoluk, Ş. (2010). Adaptation of revised two factor study process questionnaire (R-SPQ-2F) to Turkish. Education and Science, 35(157), 55-67.

Phan, H. P. (2006). Examination of student learning approaches, reflective thinking, and epistemological beliefs: A latent variables approach. Electronic Journal of Research in Educational Psychology, 4(10), 577-610.

Phillips, P. (2016). Flippin' education: A new pedagogy for paramedic students? Journal of Paramedic Practice, 8(7), 338-342.

Post, J. L., Deal, B., \& Hermanns, M. (2015). Implementation of a flipped classroom: Nursing students' perspectives. Journal of Nursing Education and Practice, 5(6), 25-30.

Rose, K. K. (2009). Student perceptions of the use of instructor-made videos in online and face-to-face classes. MERLOT Journal of Online Learning and Teaching, 5(3), 487-495.

Şen, E. Ö., \& Hava, K. (2020). Prospective middle school mathematics teachers' points of view on the flipped classroom: The case of Turkey. Education and Information Technologies, 25(5), 3465-3480.

Senemoğlu, N. (2011). College of education students' approaches to learning and study skills. Educational and Science, 36(160), 65-80. 
Şengel, E. (2016). To FLIP or not to FLIP : Comparative case study in higher education in. Computers in Human Behavior, 64, 547-555.

Shih, W.-L., \& Tsai, C.-Y. (2017). Students' perception of a flipped classroom approach to facilitating online project-based learning in marketing research courses. Australasian Journal of Educational Technology, 33(5), 32-49.

Sletten, S. R. (2017). investigating flipped learning: Student self-regulated learning, perceptions, and achievement in an introductory biology course. Journal of Science Education and Technology, 26(3), 347-358.

Steen-Utheim, A. T., \& Foldnes, N. (2018). A qualitative investigation of student engagement in a flipped classroom. Teaching in Higher Education, 23(3), 307324.

Sun, J. C. Y., Wu, Y. T., \& Lee, W. I. (2017). The effect of the flipped classroom approach to OpenCourseWare instruction on students' self-regulation. British Journal of Educational Technology, 48(3), 713-729.

Trowler, V. (2010). Student engagement literature review. The Higher Education Academy, 11(1), 1-5.

Tse, W. S., Choi, L. Y. A., \& Tang, W. S. (2017). Effects of video-based flipped class instruction on subject reading motivation. British Journal of Educational Technology, 1-14.

Tütüncü, N., \& Aksu, M. (2018). A systematic review of flipped classroom studies in Turkish education. International Journal of Social Sciences and Education Research, 4(2), 207-229.

Willms, J. D. (2003). Student engagement at school: A sense of belonging and participation: Results from PISA 2000. OECD publishing.

Yang, C. C. R. (2017). An investigation of the use of the flipped classroom pedagogy in secondary english language classrooms. Journal of Information Technology Education: Innovations in Practice, 16, 1-20.

Y1lmaz, R., \& Baydas, O. (2017). An examination of undergraduates' metacognitive strategies in pre-class asynchronous activity in a flipped classroom. Educational Technology Research and Development, 65(6), 1547-1567.

Zainuddin, Z., Haruna, H., Li, X., Zhang, Y., \& Chu, S. K. W. (2019). A systematic review of flipped classroom empirical evidence from different fields: What are the gaps and future trends? On the Horizon, 27, 72-86. 